16012-EEF

Competition in Retail Electricity

Markets: An Assessment of Ten Year Dutch Experience

Machiel Mulder Bert Willems 
SOM is the research institute of the Faculty of Economics \& Business at the University of Groningen. SOM has six programmes:

- Economics, Econometrics and Finance

- Global Economics \& Management

- Human Resource Management \& Organizational Behaviour

- Innovation \& Organization

- Marketing

- Operations Management \& Operations Research

Research Institute SOM

Faculty of Economics \& Business

University of Groningen

Visiting address:

Nettelbosje 2

9747 AE Groningen

The Netherlands

Postal address:

P.O. Box 800

9700 AV Groningen

The Netherlands

T +3150363 9090/3815

www.rug.nl/feb/research 


\title{
Competition in Retail Electricity Markets: An Assessment of Ten Year Dutch Experience
}

\author{
Machiel Mulder \\ University of Groningen, Faculty of Economics and Business, Department of Economics, \\ Econometrics and Finance \\ machiel.mulder@rug.nl \\ Bert Willems \\ CentER and TILEC, Department of Economics, Tilburg University
}




\title{
COMPETITION IN RETAIL ELECTRICITY MARKETS:
}

\section{An ASSESSMENT OF TEN YeAR DUTCH EXPERIENCE ${ }^{1}$}

\author{
Machiel Mulder ${ }^{2} \&$ Bert Willems ${ }^{3}$
}

\begin{abstract}
This paper examines a decade of retail competition in the Dutch electricity market and discusses market structure, regulation, and market performance. We find a proliferation of product variety, in particular by the introduction of quality-differentiated green-energy products. Product innovation could be a sign of a well-functioning market that caters to customer's preferences, but it can also indicate a strategic product differentiation to soften price competition. Although slightly downward trending, gross retail margins remain relatively high, especially for green products. Price dispersion across retailers for identical products remains high, as also across products for a single retailer. We do not find evidence of asymmetric pass-through of wholesale costs. Overall, the retail market matured as evidenced by fewer consumer complaints and higher switching rates. A fairly intensive regulation of mature energy retail markets appears to be needed to create benefits for consumers.
\end{abstract}

Keywords: retail electricity market, competition, regulation, ex-post assessment

\footnotetext{
${ }^{1}$ The authors thank colleagues from the Authority of Consumers \& Market (ACM), and participants at seminars at Tilburg University, Toulouse University and the KNAW workshop on energy retail markets for comments. The authors are, however, fully responsible for any remaining shortcomings. The contents of this paper do not constitute any obligation on the ACM.

2 University of Groningen, Faculty of Economics and Business / Authority for Consumers \& Markets. Corresponding author. E-mail: machiel.mulder@rug.nl. T: +31 (0) 50 3637018; P.O.Box 800, 9700 AV Groningen, The Netherlands.

${ }^{3}$ CentER and TILEC, Department of Economics, Tilburg University. E-mail: bwillems@ tilburguniversity.edu.
} 


\section{INTRODUCTION}

While the liberalization of wholesale energy markets and the introduction of high-powered incentive regulation for energy networks have been extensively studied, evidence on retail energy market remains scarce and is often limited to the early adopting countries, Norway and the Great Britain. Many studies raise concerns about the competitive nature of retail markets, and identify problems that are associated with a lack of active consumer participation and retail market concentration.

Wilson et al. (2010) show that even in a mature and transparent retail market as Great Britain's, consumers often make suboptimal choices and switch to more expensive contracts. The British regulator (Ofgem, 2011b) reckons that the competitiveness of the market has deteriorated in several dimensions, e.g. switching rates have dropped drastically. However, those developments may be attributed at least partially to too restrictive price interventions by the British regulator (Littlechild, 2014), and might not be universally valid. For the Norwegian retail market, Von der Fehr and Hansen (2008) show the coexistence of a very competitive market segment with low mark-ups and active consumers, and a monopolistic market segment where suppliers may exploit the consumers' passivity. Norway is however particular given the very large number of retail companies, and the public ownership of many retailers. Using detailed price and consumption data for Ireland, Hyland et al. (2013) conclude that retail margins vary strongly across households, an indication of price discrimination by retailers.

In their cross-country monitoring report, European regulators (ACER/CEER, 2015) conclude that many retail markets remain very concentrated with aggregate market share for the 
three largest electricity retailers of $70 \%$ or more. ${ }^{4}$ Across the board, strong product innovation is observed especially regarding contract duration, additional services and sustainability.

Overall, it appears that the transition towards a competitive and efficient retail market depends on the ability and the willingness of individual well-informed households to actively search for and select contracts that best fit their needs (see also Ofgem, 2011). However, although aggregate market developments are similar across member states, idiosyncratic differences in regulation and market structure (as the differences between Norway and Great Britain illustrate), are likely to have large effects on market outcomes. In order to understand those linkages, it is therefore important to clearly document the evolution of both market structure and regulation.

This paper provides an in-depth analysis of the evolution of competition in the Dutch retail energy market since its full opening in 2004. During this period, the regulatory framework moved from a light-handed approach to an intermediate form of market regulation. The fairly intensive market supervision aims at improving competition by eliminating possible market failures, whose results we might expect to observe in market outcomes.

In order to assess the intensity of retail competition and the benefits for consumers, we analyse market structure, product innovation, pricing strategies, gross retail margins as well as consumer behaviour. The analysis relies on a dataset collected by ACM, containing monthly prices for all products offered in the Dutch retail electricity markets over the period 2008-2014. We find that the Dutch retail market remains concentrated, despite a number of entrants, as entrants remain small and some retailers have merged. The number of products has increased strongly, while the gross retail margin decreased slightly. However, price differences between retailers remain high. We do not find evidence of asymmetric pass-through of wholesale prices. In

\footnotetext{
${ }^{4}$ Exceptions are Austria, Denmark, Finland, Germany, Great Britain, Norway, Slovenia, and Sweden.
} 
general the functioning of the retail market appears to have improved given the strong decline in the number of consumers' complaints.

The structure of this paper is as follows. Section 2 discusses the literature on retail markets, both from a theoretical and an empirical perspective. Section 3 offers an overview of the regulation of the Dutch retail energy market. Section 4 describes the method of analysis and presents the data. The results of our analysis are presented in Section 5, while Section 6 gives the conclusions.

\section{LITERATURE REVIEW}

Since the start of liberalization of energy markets, the need for retail competition and its potential benefits for consumers have been subject to debate. Joskow (2000) sees a rather limited role for retail markets in the energy sector, as many of the traditional roles of the retail market are irrelevant for energy (after-sales service, convenient delivery location and time). He states that competition in retail energy markets is useful mainly for the provision of additional services (insurance, energy services), but that regulated distribution-network operators should provide a basic retail product for the delivery energy with a price indexed on the wholesale price. In contrast, Littlechild (2000) argues that the retail market is all about price competition and that downstream competition is a necessary component for creating competition in the wholesale market.

One of the predominant features of retail market competition is the large fraction of dormant or passive consumers. They do not search or switch, but stay with the default retailer. Armstrong (2014) models the strategic decisions of retailers in several search models when there are two types of consumers: savvy and non-savvy consumers and analyses the externalities 
between both groups. Savvy consumers shop for the best deal in the market, which induces retailers to lower prices and increase product quality. If retailers cannot distinguish between consumer groups, non-savvy consumers will also benefit from those improvements. Hence, there may be positive externalities. However, Armstrong shows this depends crucially on the set-up: savvy consumers may also create a negative (rip-off) externality for non-savvy consumers if higher prices for non-savvy consumers are used to subsidize savvy consumers.

In a search model with homogenous goods based on Varian (1980), Armstrong (2014) shows that the fraction of savvy and non-savvy consumers affects price dispersion in a nonmonotonic way. If all consumers are savvy, all retailers charge the same low price and price dispersion is non-existent. With a mixture of consumer types, price dispersion exists as retailers use mixed pricing strategies. In that case savvy consumers pay less than non-savvy consumers. At the other extreme, if all consumers are non-savvy, retailers charge the same monopoly price, and price dispersion is non-existent again. The impact of the share of savvy consumers on price dispersion is therefore inversely U-shaped. Those predictions find empirical support. Brown and Goolsbee (2002) estimate the effect of price-comparison websites on prices in the life-insurance industry and find an initial growth in of price dispersion before it declines. In an empirical analysis of prices in retail food markets, Anania and Nisticò (2014) find significant price dispersion in spite of the fact that these markets are characterised by homogeneous products, frequently repeated purchases, a high number of sellers and relatively low search costs. From those papers, it is clear that the amount of price dispersion is not a direct indicator for the intensity of price competition, but that other factors might drive changes, like (perceived) heterogeneity of the retailers, and individuals' search propensity. 
When discussing the efficiency of retail markets, a key aspect is the pass-through of upstream costs to downstream prices. In many retail markets, wholesale price increases are passed on faster to final end-users than decreases, a phenomenon called rockets and feathers (Peltzman, 2000). ${ }^{5}$ The literature proposes several explanations for those effects. If price adjustments are costly and on average prices increase with inflation, it might be optimal not to adjust price downwardly. Another explanation for this asymmetric relationship refers to adjustment costs in technology. If capacity constraints exist in the downstream market, firms in this market do not face competitive pressure to pass on upstream cost reductions (Borenstein and Shepard, 2002). A third explanation is related to competition and search effects. The search intensity by consumers declines when prices decrease, and as a result firms face less competitive pressure to pass on cost reductions (Lewis and Marvel, 2011). ${ }^{6}$ Empirical evidence for the rockets and feathers effects was found for the UK and Norwegian retail electricity market by Ofgem, (2011c), Von der Fehr et al. (2009) and Mirza et al. (2012). The latter show that faster downward adjustments of prices would have resulted in considerable consumer savings.

The European energy directives are in line with Littlechild's view on retail competition. They introduce full price competition for all households soon after the wholesale market liberalization. However, in many member states some price regulation remains. Few papers have studied the effects of regulatory interventions in the energy retail sector. Waddams-Price et al. (2016) analyse the introduction of the non-discrimination clause (NDC) in the UK retail market in

\footnotetext{
${ }^{5}$ The Rockets and Feathers literature is vast. One of its main applications is the study of gasoline retail prices, a market where products are also rather homogenous (Borenstein 1991). Meyer and von Cramon-Taubadel (2004) and Eckert (2013) provide surveys.

${ }^{6}$ Recent papers endogenize both search intensity and the strategic price setting by firms. See Yang and Ye (2008), Tappata (2009), and Cabral and Fishman, (2012).
} 
2008. ${ }^{7}$ Before the introduction, incumbent retailers charged about $10 \%$ higher tariffs in their former monopoly region than in other regions where they were entrants. After the introduction of the pricing constraint, initiated by the regulator for fairness concerns, price differences between incumbent and major competitors (having a different home region) indeed decreased. The authors report, however, that the profit margins increased from almost none to over 100 pounds per consumer in 2013. This implies that the NDC mainly resulted in higher tariffs in non-home regions instead of lower tariffs for consumers in the home region. Switching rates also fell as result of the smaller price differences.

The distinction between active and passive consumers may be more pronounced in the electricity sector than in many other sectors. As the market evolved from a fully regulated market, many customers have never consciously chosen for a particular contract, but simply continued with their incumbent retailer on a default contract. Von der Fehr et al. (2009) distinguish active (savvy) and passive (non-savvy) consumers in the Norwegian market, and argue that active consumers might have benefited from larger product variety caused by the liberalization, but passive consumers did not experience real benefits from liberalization.

\section{REGULATION OF THE DUTCH RETAIL ELECTRICITY MARKET}

Before the liberalisation of the Dutch retail market, energy consumers were supplied by a regulated, vertically integrated incumbent with a regional monopoly for electricity distribution and retail. After a gradual liberalization of the Dutch retail market, which started for large industrial users in the nineties, followed by a partial opening for green electricity products in 2001, all

\footnotetext{
${ }^{7}$ See also Littlechild (2014).
} 
consumers were free to choose a supplier in 2004 (Van Damme, 2004). Since 2004, a number of regulatory measures have been implemented (Table 1).

The agency responsible for regulating the energy market is the Authority for Consumers \& Markets (ACM), which was created in 2013 by the merger of the Competition Authority NMa (which was responsible for energy regulation until then), the Consumer Authority and the Telecom and Post regulator (OPTA). Since the merger, the regulation of energy retail markets is increasingly based on general consumer protection legislation and less on sector-specific legislation. Regulation consists of four components: 1) structural measures, 2) contract restrictions, 3) information provision and transparency and 4) monitoring.

Table 1 Regulatory events in the Dutch retail energy markets since 2004

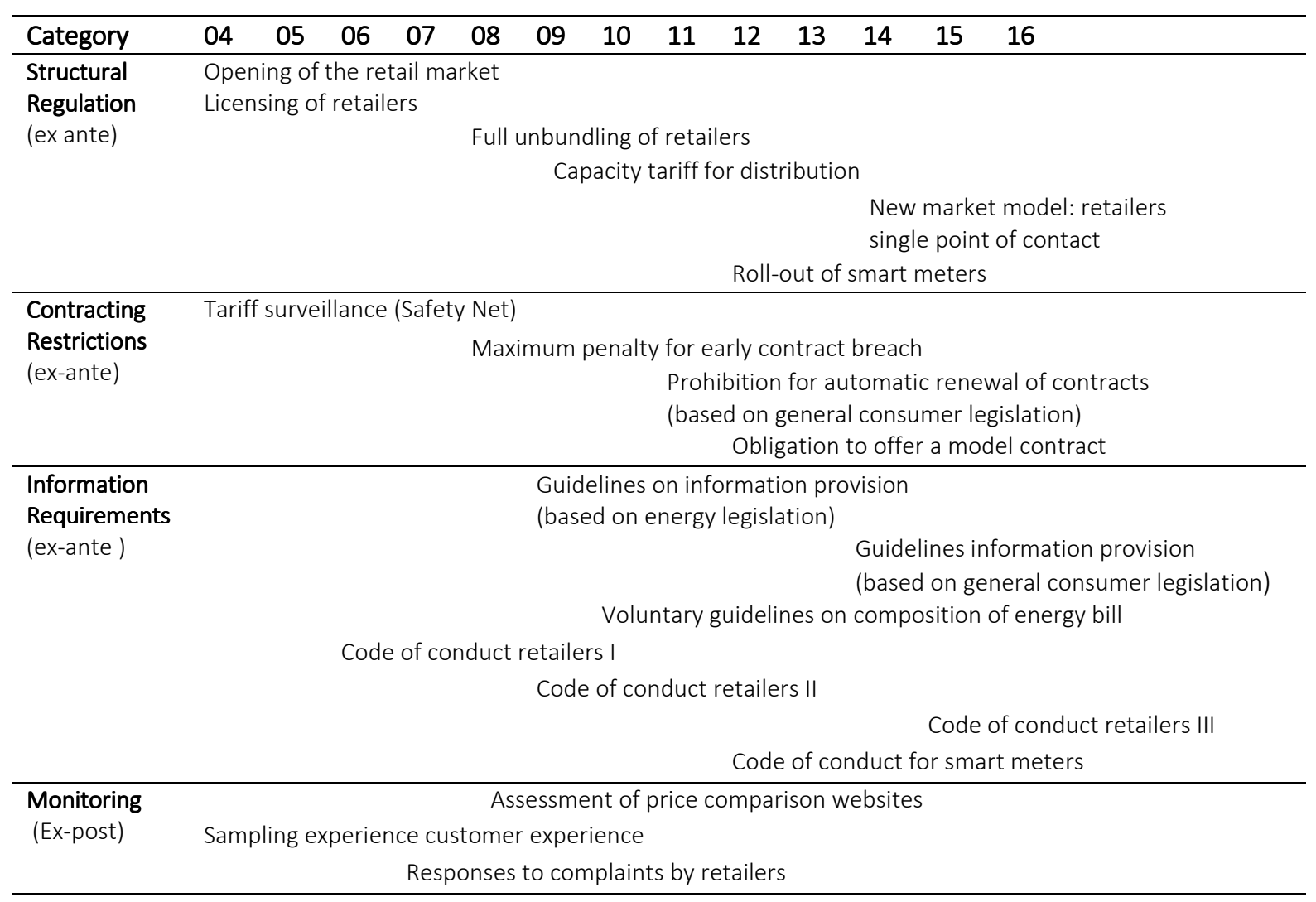


The structural measures include licensing requirements for retailers, full unbundling of retailers, and the allocation of responsibilities within the energy chain. A retail licence is a prerequisite for becoming active in the market, and is granted to firms that are sufficiently solvent and have satisfactory organizational capabilities. ${ }^{8}$ In 2008 , energy-distribution companies were forced by the government to unbundle ownership of commercial activities, such as generation, trading and retailing, from network operation. Network operation and ownership, however, could not be privatized and remained in hands of local and national governments. Both measures were meant to guarantee the independence of infrastructure operators, improve competition and in particular facilitate decentralized (renewable) energy production (Mulder et al., 2006).

A significant change in the responsibilities of network operators was the introduction of the so-called new market model in 2013 , which prescribes that retailers receive full responsibility for managing the switching processes on behalf of the consumers. Retailers have become the single point of contact for households, who receive a single bill consisting of both retail and distribution charges. As a first step towards the introduction of the new market model, a capacitybased transport tariff was introduced in 2009. Since a number of years, the metering infrastructure belongs to the exclusive responsibility of the network operators, while retailers are responsible for the collection of metering data. Since 2012, network operators are obliged to gradually offer all consumers smart meters, although consumers can opt-out and keep using the standard meters.

The second group of regulatory measures consists of restrictions on contracts offered by the retailers. These restrictions include a maximum on the penalty that consumers have to pay in case of early contract breach as well as the prohibition of automatic renewal of contracts. The

\footnotetext{
${ }^{8}$ Once a retailer obtains a licence, only light-handed financial monitoring takes place as the regulator has limited legal power to intervene if a retailer does not meet financial criteria. If a retailer goes bankrupt, its retail licence is revoked. Supply to its customers is then guaranteed by the network operator, until customers are transferred to another retailer.
} 
second restriction is based on general consumer legislation, while the first one follows from sector-specific regulation. In order to improve market transparency the legislator ${ }^{9}$ decided that each energy retailer should offer a standardized product that is identical across retailers on all aspects except price. In cooperation with the industry and consumer organizations, the regulator therefore issued a model contract (NMa, 2012). This model contract prescribes the contract in all its details (product type, general conditions, etc.). However, this standardized product is hardly sold, which may be related to the fact that retailers cannot use this product for special offers due to the strict regulations on the conditions.

A specific element of regulation is the "safety net" regulation. Although the legislator agrees that in principle a free market will lead to reasonable market prices, the regulator is required to prevent unreasonable prices and to protect passive consumers. Four weeks before a new contract results in delivery of energy to consumers or four weeks before a price change, retailers are required to submit the contract to the regulator, which will check whether the contracting conditions and in particular the price, are not unreasonable. In theory, the safety net could have adverse effects on competition. If a price cap would be announced publically, it could become a focal point for retailers. The regulator therefore does not disclose its assessment methodology. With a too strict safety net, the role of the retail competition is hollowed out: price differences are reduced and consumers will no longer search actively for new products.

The third group of measures are information requirements. Many of the regulations on information provision have the form of voluntary codes of conducts (self-regulation), or become official regulation by ACM's endorsement of a text upon which stakeholders have already agreed. Codes of conduct are meant to improve market transparency (by making information more

\footnotetext{
${ }^{9}$ Amendment to the 1998 Electricity Act (Stb, 2011, 203).
} 
comparable), but also to prevent abuses (telemarketing, colportage). The Code of Conduct III includes the rule that retailers need to precisely inform consumers what their annual costs of a specific offer will be. This rule is based on general consumer legislation.

Finally, the regulator closely monitors the energy retail market and publishes information to make the market more transparent. The regulator assesses on an ad-hoc basis the quality, in particular the independence and transparency, of the existing price-comparison websites. In addition, the regulator provides information on the retail energy market on a government website directed to consumers ( $\underline{w w w . c o n s u w i j z e r . n l})$. This website is not sector-specific, but contains some pages with specific information about energy markets. At this site consumers can also signal problems to the regulator.

\section{METHOD AND DATA}

\subsection{Method}

We use several indicators to assess how the Dutch retail energy market has developed. A first set of indicators are measures for industry structure. Although the relationship between industry structure and competition is not unambiguous, changes in the structure are informative about the dynamics on the supply side. New firms can enter the market, and lower market concentration. At the same time, less efficient retailers are likely to lose market share or to be taken over by competitors. We measure the horizontal market structure by the HHI and the market shares of the major players.

As indicator for dynamic efficiency, we use product and service innovation, measured by the number of products offered to consumers. Note that product variety is not necessarily a good measure of market efficiency, and should therefore be carefully considered. It is well-known 
that even in a market without entry barriers, variety might be too large or too small (Dixit and Stiglitz, 1977). Moreover, an increase in the number of products may also hinder competition if it reduces market transparency and increases switching costs.

To analyse the pricing strategies of firms, we focus on a subset of contracts - contracts with fixed and variable retail prices with a limited duration of one year for both green and grey electricity. The variance in retail prices across retailers also offers information about the degree of competition. Large price divergences may be a sign of lack of transparency and difficulties for consumers to compare prices, but it can also be related to consumer inertia (ACER, 2015). In the case of homogeneous markets with search costs, the price bound between the lowest and the highest prices can be used as an indicator for the intensity of competition: the lower this bound, the more intense competition is. We will, therefore, also look at the evolution of the variance in retail prices over time. Models with search cost and homogenous goods find that in equilibrium, firms randomize prices, and that there is no clear price leader that is always the cheapest (hence, there is some leap-frogging). If a single firm is always the price leader, then this simple search model does not hold.

As indicator for the intensity of price competition in the retail market we look at gross retail margins. In a perfectly competitive market with homogenous products, gross retail margins are equal to the marginal costs of retailing, leaving no room for surplus profits. This is however no longer the case if retailers have some market power for instance because products are (seen to be) differentiated. We estimate the gross margins in the Dutch retail energy market by comparing the retail prices for a subset of product types with the relevant wholesale price. We assume that the 
relevant wholesale price can be based on the duration of the contracts. ${ }^{10}$ Referring to Von der Fehr et al. (2009), we estimate the following equation:

$$
p_{t}^{r}=\beta_{0}+\beta_{1} p_{t}^{w}+\beta_{2} p_{t-1}^{r}+\varepsilon_{t}
$$

where $p_{t}^{r}$ and $p_{t}^{w}$ are the retail and wholesale price at month $t$, and $p_{t-1}^{r}$ the retail price in the previous month and $\varepsilon_{t}$ the error term. We assume that marginal retail costs have not changed significantly. By further assuming a steady-state situation in which $p_{t}^{r}=p_{t-1}^{r}=p^{r}$, and ignoring the error term, we are able to write the retail price as a function of the wholesale price:

$$
p^{r}=\frac{\beta_{0}}{1-\beta_{2}}+\frac{\beta_{1}}{1-\beta_{2}} p^{w}
$$

which means that in the long run the retail price consists of a constant plus fraction of the wholesale price. The relative mark-up can now be determined as follows:

$$
\frac{p^{r}}{p^{w}}=\frac{\beta_{0}}{1-\beta_{2}} \frac{1}{p^{w}}+\frac{\beta_{1}}{1-\beta_{2}}
$$

In addition, we analyse the symmetry in the pass-through of changes in wholesale costs to the retail prices. Using the error-terms of the long-term relation, we estimate an error-correction model in order to determine how changes in the wholesale price affect changes in the retail price. We estimate the following relationship:

${ }^{10}$ For 1-year fixed price contracts, the relevant wholesale price is the 1-year forward price at the time the retail product is sold. As retailers generally update the prices in their variable-price contracts every quarter, we assume that the relevant wholesale price for these contracts is the 1-quarter forward price. 


$$
\Delta p_{t}^{r}=\beta_{0}+\beta_{1} \Delta p_{t}^{w}+\beta_{2} \varepsilon_{L T}^{\stackrel{+}{t-1}}+\beta_{3} \varepsilon_{L T T-1}^{-}+\varepsilon_{t}^{r},
$$

where $\Delta p_{t}^{r}$ is the first difference of the retail price, $\Delta p_{t}^{w}$ is the first difference of the wholesale price, $\varepsilon_{L T-1}^{+}$is the error term of the cointegration equation if it has a positive value and $\varepsilon_{L T-1}^{-}$error term of the cointegration equation if it has a negative value. The hypothesis is that the coefficients $\beta_{2}$ and $\beta_{3}$ are both negative. If $\varepsilon_{L T-1}$ is positive, the actual retail price is above the long-term estimation and one may expect that the price will go down. Otherwise, if $\varepsilon_{L T-1}$ is negative, the actual retail is below the prediction based on the long-term estimation, and as a result one may expect that the price will go up. ${ }^{11}$ If the upward and downward effects of the wholesale price on the retail price are symmetric, then coefficients $\beta_{2}$ and $\beta_{3}$ should be equal.

Finally, we look at consumers' behaviour. A first indicator is the number of complaints filed by consumers at the Dutch Court of Arbitration regarding energy retailers. As consumers become more satisfied with the functioning of the retail market, we expect this number to decline. The second indicator is the switching rate, the yearly number of consumers choosing a different retailer. There is no monotonic relationship between switching rates and competition intensity as in both a market with perfect competition (and hence equal prices) and a market without any competition (i.e. a monopolistic market), consumers will never switch. In combination with information about price differences, it may give some insight into the search intensity of consumers.

\footnotetext{
${ }^{11}$ Because in that case, $\varepsilon_{L T}$ is negative, a negative coefficient is required to obtain a positive effect on the retail price.
} 


\subsection{Data}

We use anonymized data collected by the ACM, which contain 11.000 new price - product combinations offered by the 32 retailers that operated in the Dutch electricity and gas market over the sample period (Jan 2008-Dec 2014). For this study, we limit ourselves to electricity contracts offered to households. Hence, we do not look at interaction with the retail gas market ${ }^{12}$ and neglect contracts for smaller industrial or commercial consumers that buy electricity from retailers.

This data set does not contain information when specific contracts are withdrawn from the retail market. We therefore assume that each price-contract combination once it is offered will remain available on the retail market for six months, unless it is being replaced at an earlier moment by an identical product offered by the same retailer at a different price level. Across time, products are assumed to be identical, if they are sold under the same (commercial) name or, if almost all contract specifications are identical and for a window of ca. 3 months before and after the newer contract, no closer match exists. ${ }^{13}$ Contracts are mainly classified by contract duration, pricing flexibility (fixed of variable), primary fuel, and sales channel. Sometimes those specifications are insufficient to uniquely determine a specific contract and in these cases individual contract specifications are checked on the websites of retailers. This data is codified to construct a multi-dimensional panel data (time, retailer, and contract type). Given the frequency of adjustment, we use a monthly resolution for the time variable. Note that the contract types

\footnotetext{
${ }^{12}$ Most retailers offer dual fuel contracts. However, the conditions (price, type of product) for the electricity product are not fundamentally different from single fuel electricity contracts. In contrast to the UK market, dual fuel contracts already existed before the liberalization, and there is no incumbent gas retailer, that acted as a new entrant in the electricity retail market.

${ }^{13}$ Commercial product names might change every few years for what are essentially identical products. When we build our time series we try to follow products across those name changes. Even if a new commercial product is introduced, old commercial products might be phased out only gradually (e.g. by being available only for existing customers). In that case we use the price of the newly introduced product. Contract prices are often adjusted at regular intervals, which allows us to match different contracts more easily over time.
} 
themselves could be considered a multi-dimensional variable describing contract duration, pricing flexibility, primary fuel etc.

The pricing of retail contracts generally are non-linear and consist of a yearly fixed term $f$ (in EUR / Yr.) and a variable energy component $v$ (in EUR/MWh). ${ }^{14}$ In order to make contracts comparable, we calculate the average electricity price (EUR/MWh) for an average household that consumes approximately 3.2 MWh/year by using the following formula: ${ }^{15}$

$$
p=\frac{f}{3.2}+v
$$

In order to compare prices across retailers, for each retailer four composite benchmark products are created: a fixed 1 year green contract, a fixed 1 year grey contract, a variable green contract and a variable grey contract. ${ }^{16}$ For the composite benchmark product, we neglect contracts representing short duration offers, and contracts that are not available to all consumers or specific promotions. ${ }^{17}$ If a retailer offers contracts with similar specifications at a given moment in time, but with pricing formulas targeting households with different consumption volume (by offering a menu of contracts with different fixed and variable pricing components), the cheapest contract for a yearly consumption of 3.2 MWh is considered. For the variable-price contracts, we combine contracts with an unlimited duration (which can be cancelled at no costs) and contracts of one-year duration (which may require a cancellation fee when contracts were finished before the

${ }^{14}$ Only a small fraction of consumers opts for "Time-of-Use" pricing (which requires a special meter, and has a different price setting at night and day). We therefore neglect those types of contracts.

${ }^{15}$ The importance of the fixed component $f$ in the electricity price has increased over time from ca. 20 EUR/Yr. to ca. $35 \mathrm{EUR} / \mathrm{Yr}$.

${ }^{16}$ In the variable-price contracts, generally the prices are adapted every quarter or half year. As a result, this type of contracts can also be called fixed quarter or half-year contracts.

${ }^{17}$ We discard for instance contracts offered to consumer collectives, special prices offered to retention consumers, contracts with best-price guarantees, transitional contracts during mergers, contracts with additional services or applications (like smart meters), and any exotic pricing formulas (only decreasing, temperature dependent, wind speed dependent, a mixture of fixed and flexible), or targeting specific users (for charging electric cars). 
end of the contract). ${ }^{18}$ As the composite price for the green products, we take the cheapest available contract for green electricity for each retailer. By selecting the cheapest contract, which is often based on Nordic Hydroelectricity, contracts become more comparable. ${ }^{19}$

From our database, we cannot observe the actual prices that consumers pay, as there are often promotional offers, and many promotions are not fully registered in the database. Those promotions could take the form of an upfront switching bonus, an introductory price for a limited duration, or a loyalty price (where prices decrease over time), and often depend on the sales channel (e.g. door-to-door, comparison website, own website, in a physical shop).

In order to estimate the retail margins, we use two benchmark products for wholesale electricity prices. For the variable-price contracts we take a quarterly forward contract, since retailers usually update these prices every 3 months. For the 1-year fixed-price retail contracts, we take the 1-year forward contract. ${ }^{20}$ Forward contracts are traded on a daily basis and might fluctuate considerably from day to day given limited liquidity on some days. We therefore use the average closing price during a ten-day window around the first day of the month. Since retail prices have to be submitted to the regulator for an assessment one month before the energy is delivered to consumers, they can only be based on market information that is at least one month old. We therefore compare retail price with wholesale prices that are lagged at least one month. ${ }^{21}$

\footnotetext{
${ }^{18}$ One-year contracts with variable price form only a small fraction of this group. Most contracts with variable prices have an unlimited duration. Note that a contract with variable prices and a fixed duration may be attractive to consumers because of a relative low initial price, but after the contract has been signed the retailer has the option to raise the price, making the contract less attractive ex-post.

${ }^{19}$ Retailers typically offer a vertically differentiated set of green contracts ranging from Nordic hydro (the cheapest), to European Wind, and Dutch wind energy (the most expensive).

${ }^{20}$ For both wholesale prices, we use OTC prices. Differences between the OTC price and the exchange price are negligible for the period under consideration.

${ }^{21}$ Although retailers may also make some costs for acquiring Green Certificates of Origin, there is no publicly available information on these prices.
} 


\section{RESULTS}

\subsection{Market structure}

The Dutch retail market remains fairly concentrated in spite of a number of entrants. With an HHI concentration index of 2200, it is more concentrated than the Dutch wholesale electricity market (Figure 1). Several retail companies use multiple-brand strategies. For instance Oxxio, which started as an entrant, is now a one of ENECO's brands, while Essent/RWE owns a second brand, EnergieDirect, which sells only through internet. Also GreenChoice belongs to the ENECO group (See Figure 2). All major brands are active in all regions, and retail competition is national in scale.

Figure 1 HHI of Dutch electricity wholesale and retail market, 2006-2014



The three largest retailers, the incumbents Essent, Nuon, and Eneco with their affiliated brands, serve about $80 \%$ of the market. Essent and Nuon were privatized and acquired in 2009 by RWE (Germany) and Vattenfall (Sweden), respectively. Some retailers are vertically integrated: 
RWE and Vattenfall are major international players in the wholesale market, but Eneco owns only limited production capacity. As it is not yet fully unbundled, it provides retail as well as distribution services through the network company Stedin. ${ }^{22}$ Although Engie and E.ON are large international energy firms, they focus in the Netherlands only on production, and have small market shares in the retail market. One relatively successful entrant, Nederlandse Energiemaatschappij (NEM) still has low market shares, while other entrants have been (partially) acquired by one of the incumbents (Oxxio, Greenchoice).

Figure 2 Market shares in Dutch electricity market: retail and wholesale 2013

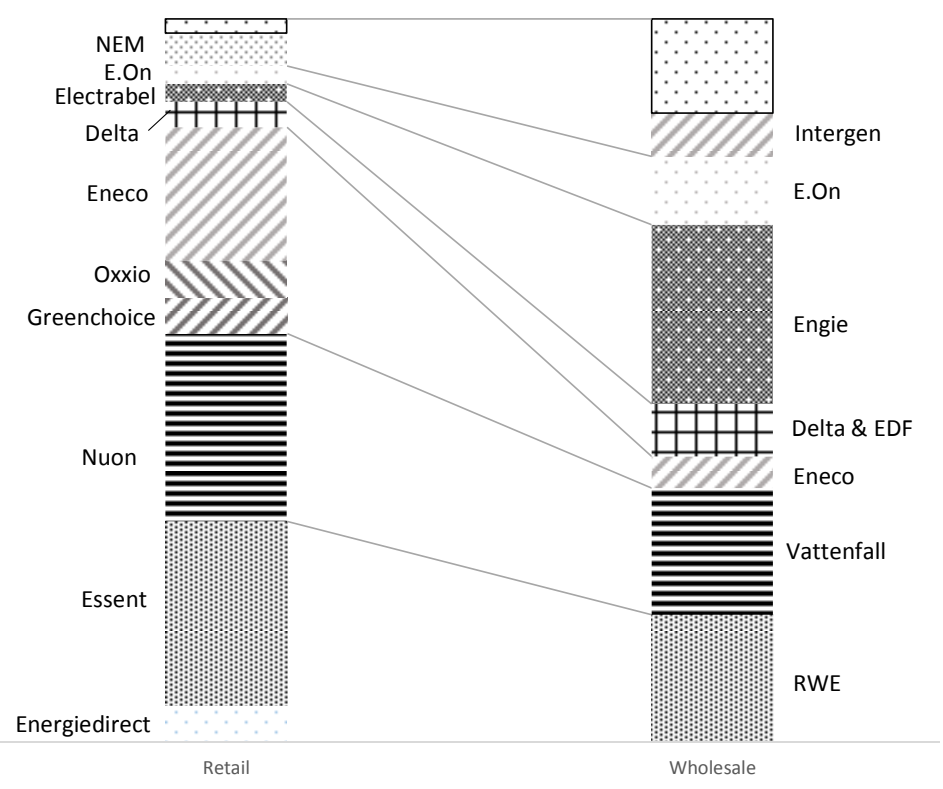

Source: Retail data: Market response (2014), Wholesale data (Mulder, 2015)

${ }^{22}$ Eneco did not unbundle yet as it waited for the decision of the court on the legality of the unbundling's law. 


\subsection{Innovation in products}

Since the opening of the Dutch retail energy market both green (100\% from renewable energy sources) and grey electricity (from a mixture of energy sources) are offered. The number of product types offered in the market has strongly increased (Figure 3). Currently, consumers can choose among about 50 green and 20 grey products offered by the 7 main brands. Hence, on average each brand offers 10 different products. Product proliferation is driven by two developments: quality differentiation in green electricity and innovation in contracting forms.

Figure 3 Number of products offered by the 7 main brands, by type (Green/Grey), 2008-2014

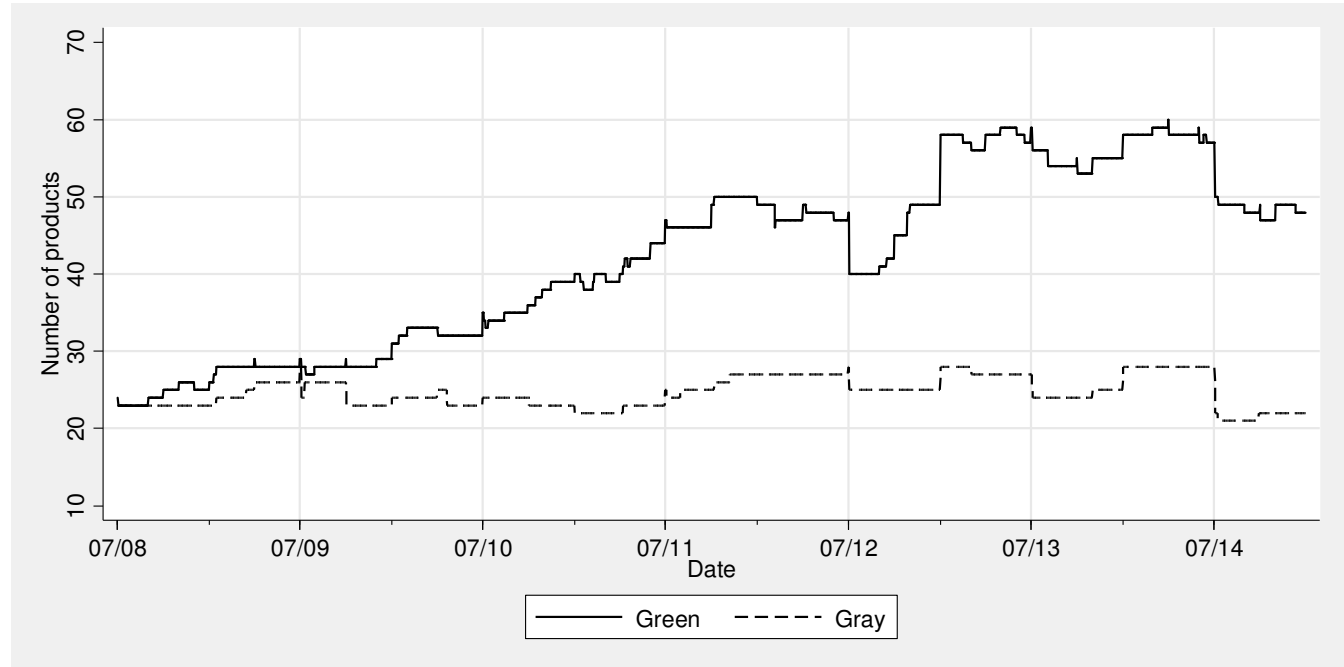

Retailers have to provide a label detailing the origin of their electricity by relying on Certificates of Origins (CoO), which is a European-wide tradeable certification system for electricity production. Retailers can bundle CoOs with wholesale electricity to construct green retail contracts (100\% from renewable energy sources) and grey electricity (from a mixture of energy sources). The market for green electricity has increased significantly. In 2014, about two thirds of electricity supplied to residential households was green, while in 2008 this share was less 
than one third (ACM, 2014). For the green products, Dutch retailers depend strongly on the import of CvOs from for instance Norway. ${ }^{23}$

From around 2011 green electricity becomes a quality-differentiated product with plain green electricity (based mainly on Nordic hydro-electricity), and premium products such as European wind, Dutch wind or Dutch solar. Consumers are prepared to pay a premium for those higher quality products. Several action committees organized information campaigns about differences in green electricity and tried for instance to shame (local) governments into buying 'more honest (Dutch) green electricity'. ${ }^{24}$ This increased product differentiation is likely to affect competition, as it is linked to specific location and technologies of production plants and can therefore not be readily copied by all retailers. ${ }^{25}$ Figure 4 shows that the number of major brands offering different quality levels of green and grey electricity products.

${ }^{23}$ About one third of national electricity consumption (industry and retail) is green, while only $10 \%$ of national electricity production is green (CentiQ, 2015).

${ }^{24}$ Since 2013, national newspapers report regularly on the issue of tampered green power, or "sjoemelstroom".

${ }^{25}$ Product differentiation puts a premium on Dutch green electricity and wind \& solar electricity. Producers with a large Dutch fossil fuel park (Essent, Nuon), and with Nordic Hydro power plants (Vattenfall), might find it difficult to offer those products. Note that, unlike some other countries, German regulation restricts the use of Certificates of Origin if companies receive German subsidies. Hence, German wind does not provide competitive pressure in the Netherlands. 
Figure 4 Number of brands offering green products (Largest 7 Brands), 2008 vs. 2013

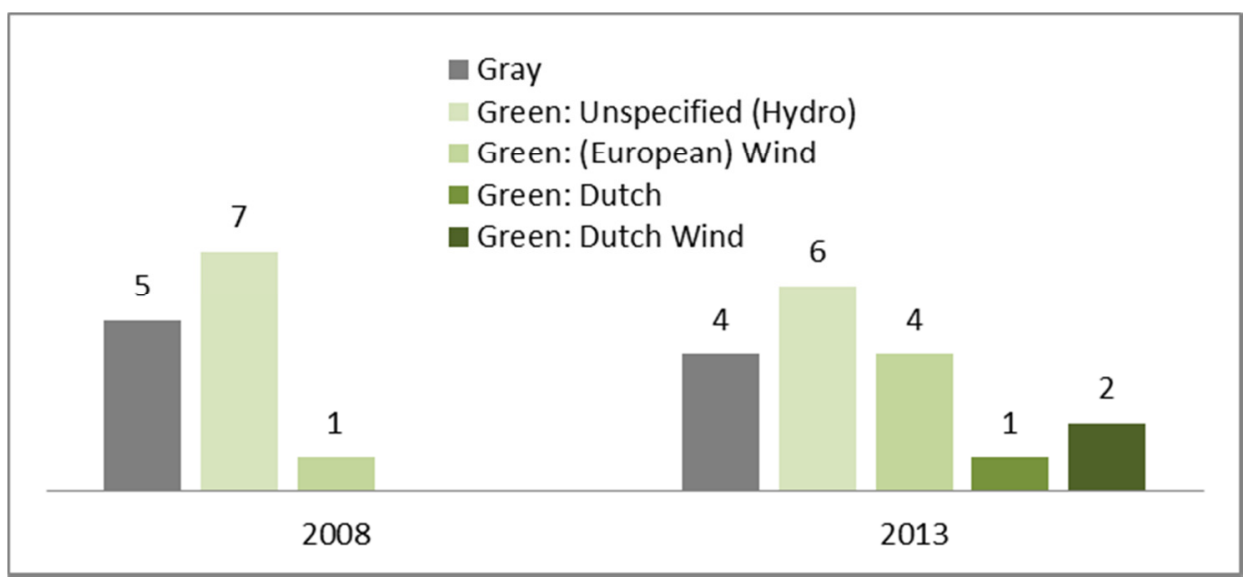

Another dimension in which products became more differentiated is their pricing structure.

Two pricing structures are offered by all brands: variable price contract and fixed price contracts. Variable-price contracts are very similar to the pre-liberalization types of contracts where prices are adjusted on a regular 3-6 months schedule. The variable prices are not explicitly indexed on wholesale spot market prices, but are set by the retailer (although still subject to the Safety Net regulation). With fixed-price contracts, households pay a fixed electricity price for a specific duration (typically 1 or 3 years). Contracts with an undetermined duration always use variable prices. If consumers do not undertake any action before the end of a contracting period, the contract is automatically transformed into a variable price contract.

Other novel types of pricing structures are introduced by a subset of brands (Figure 5). Those contracts are often part of large marketing campaigns with trademarked products. One contract type is an option contract in which prices are variable but cannot increase above their initial price. Hence, those contracts include an explicit price cap. Other contracts that affect household's risk are also offered: a combination of a fixed and variable price contract (which in effect dampens price fluctuations), prices that drop with outside temperature (and hedge against cold winters) or with higher wind speeds (which hedges the retailer, as it only offers low retail 
prices when wholesale prices are low). In fact, the last two contracts are the ones which explicitly link the retail price to the wholesale market conditions. ${ }^{26}$

In some countries electricity retailers differentiate prices based on consumer location, consumption volume and payment mechanism, but not in the Netherlands. Regional price discrimination is not very common and if it is used, then it is part of targeted local marketing efforts and prices are not widely posted. A few retailers offer volume differentiated contracts for one or two products. There is almost no price differentiation according to payment system. Directdebit consumers receive a reduction of 1 or 2 EUR on their bill, and pre-paid contracts are almost non-existent. More recently, retailers start bundling energy contracts with other services or devices (smart thermostats, i-pads, energy audits, insulation etc.).

Figure 5 Number of brands offering different types of contracts (Largest 7 Brands), 2008 vs. 2013

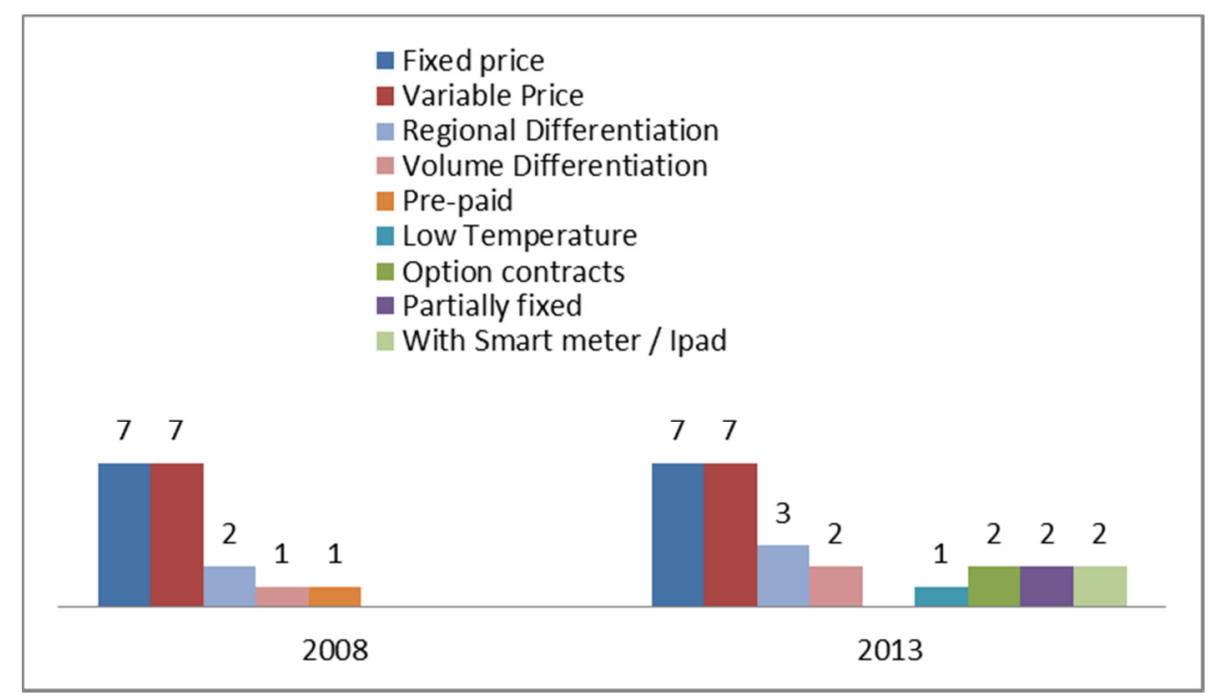

\footnotetext{
${ }^{26}$ The contract indexed on the outside temperature hedges the volume risks during colder winter months (and thus leads to negative correlation between the wholesale and the retail price).
} 


\subsection{Price comparison websites}

Since the start of the liberalization comparison websites have played an important role in the retail energy market. ${ }^{27}$ However, as products have become more numerous and more complex and as colportage and tele marketing are no longer as effective, comparison websites have become crucial for consumers to make well-informed decisions, and for retailers' overall strategies. ${ }^{28}$

Although all comparison websites are commercial entities, different market models are used. A large number of comparison websites are paid by the retailer for every consumer that signs up to a new contract. Typically those websites provide a direct link to the product on the website of the retailer, or they allow consumers to contract directly through their own website interface. The sites have a contractual relationship with one or several retailers, and are therefore able to provide special deals that are not present on the retailers' website. The most prominent special deals are cash-back offers (e.g. lump-sum payments up to 200 EUR) or reduced rates for an introductory period. Advertisement driven comparison websites do not have commercial links with the retailers, but generate revenue by the publicity on their websites and collect information of retailers themselves. As they do not have commercial links with retailers, they do not offer special deals.

In order for the retail market to function well, comparison sites should not provide preferential treatment of a small number of retailers and offer a sufficiently wide variety of products. A retailer could receive preferential treatment if certain contracts of competing retailers are not offered. Early on ACM would monitor whether all official products were offered on the comparison site, while neglecting the special deal contracts. However, as total number of contracts

\footnotetext{
${ }^{27}$ This section is based on monitoring reports frequently published by the energy regulator. (DTe, 2004; NMa, 2005; DTe, 2006, 2007; NMa, 2010, 2011)

${ }^{28}$ In the press door-to-door sales of energy products received bad publicity. In October 2009 a strict telemarketing law with an opt-out rule was introduced in the Netherlands, Stb. 2009, 129.
} 
has increased, and the number of special deals in particular, this was no longer feasible. ACM therefore (irregularly) monitors the contractual relations between retailers and comparison sites and looks at overall product variety.

The focus of comparison websites has shifted from providing price information on standardized products, to providing additional information on product types, the quality of retailers, and special contracting conditions. Most comparison sites provide correct information on the different pricing components and the yearly bill for customers. On some of the other dimensions, transparency might be lacking. For instance the specific conditions for special deals often remain unclear. ${ }^{29}$ Responsibility for providing this information is often shared between the retailer and the comparison site.

\subsection{Pricing strategies and price dispersion}

Retailers use different pricing strategies. The frequency of price adjustments differs across firms. Some retailers frequently introduce new prices, while others maintain their prices for a longer period of time. This holds for variable and fixed price contracts and for green and grey products. We also see that firms often undercut each other, and that there is no clear price leader which moves first. For the fixed price contracts, several firms have the cheapest offer for short periods.

${ }^{29}$ Sometimes cash backs will only be paid out if the consumer would stay longer than the contract duration. Once the promotion is finished, consumers might end up with a higher priced "sleepers' contract". 


\section{Figure 6}
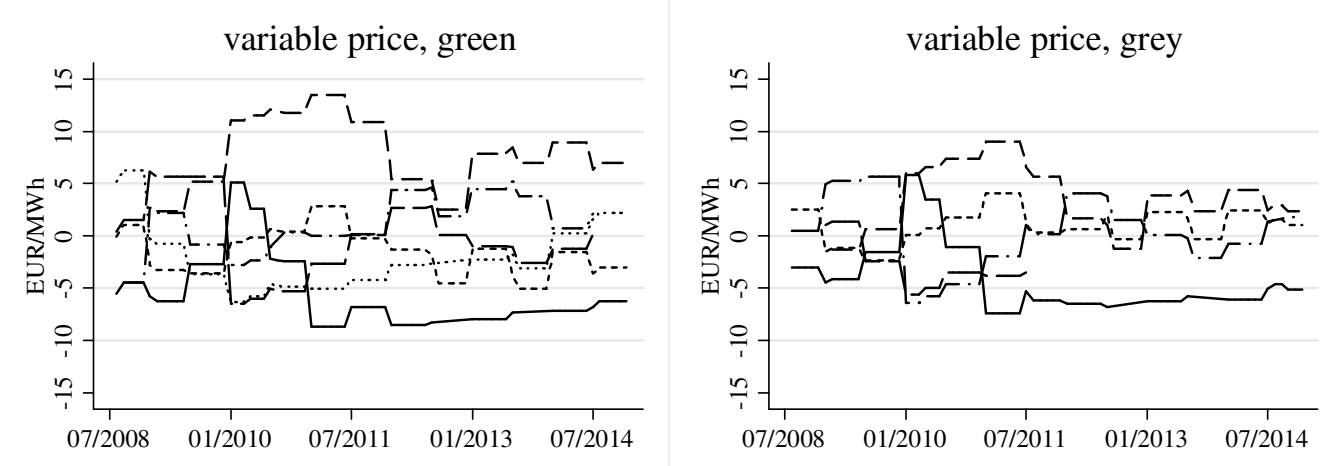

Price
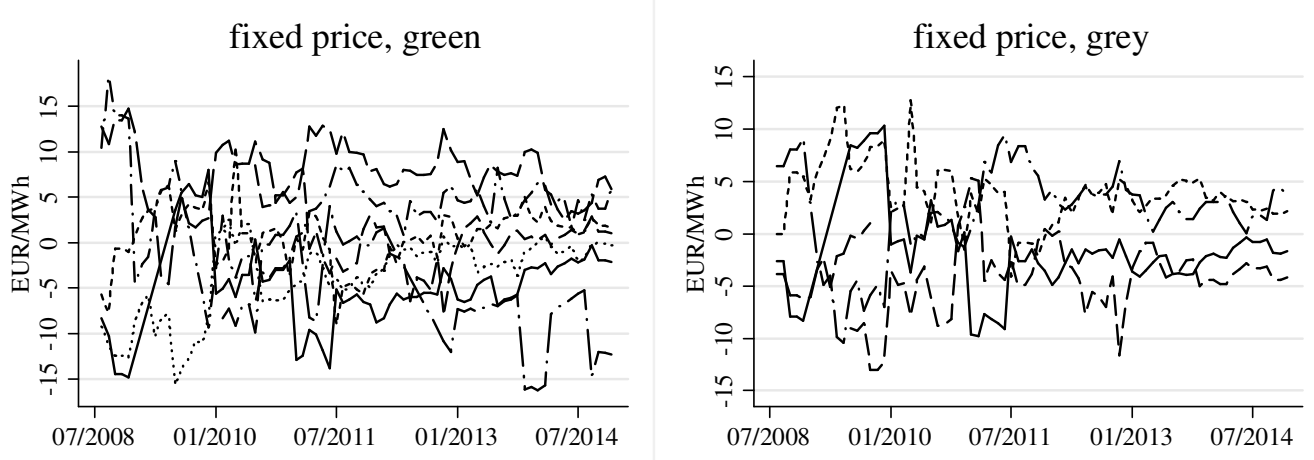

deviation

s from

average

price, by

product

type and

month,

2008-

2014 
Overall price dispersion appears rather constant over time, although there might be a slight decline for grey and fixed price contracts (Figure 6). The difference between the lowest and highest priced contract for green electricity was about 15 euro/MWh in 2014. For grey electricity this difference is much smaller. Measuring price dispersion by the standard deviation of retail prices and the differences between the highest and lowest price, we find that price dispersion has declined strongly for fixed-price products, both green and grey (Figure 7). For variable-price products, however, the price dispersion did not structurally change. The initial level of the standard deviation for fixed-price contracts was relatively high, in particular for grey products. In 2014, the price dispersion for both types of products was fairly similar.

Figure 7 Price dispersion: standard deviation of prices across firms, by product type, 2008-2014


\subsection{Retail margins}

Retail prices have declined over the past years, but this also holds to some extent for the wholesale prices (Figure 8). In order to determine how the retail margins have developed, we 
conduct a regression analysis as described in Section $4 .{ }^{30}$ The statistical tests are presented in Appendix A. As the 1-year fixed prices as well as the yearly forward wholesale prices are cointegrated non-stationary series, we are able to include the levels of these prices in the regression equation. ${ }^{31} \mathrm{We}$ conduct this analysis for the group of all 1-year fixed products over the period 2009-2014 as well as for the subgroups of green and grey products, and all products in two different sub-periods (Table 2).

Figure 8 Average retail price versus relevant wholesale price, by product type, 2008-2014
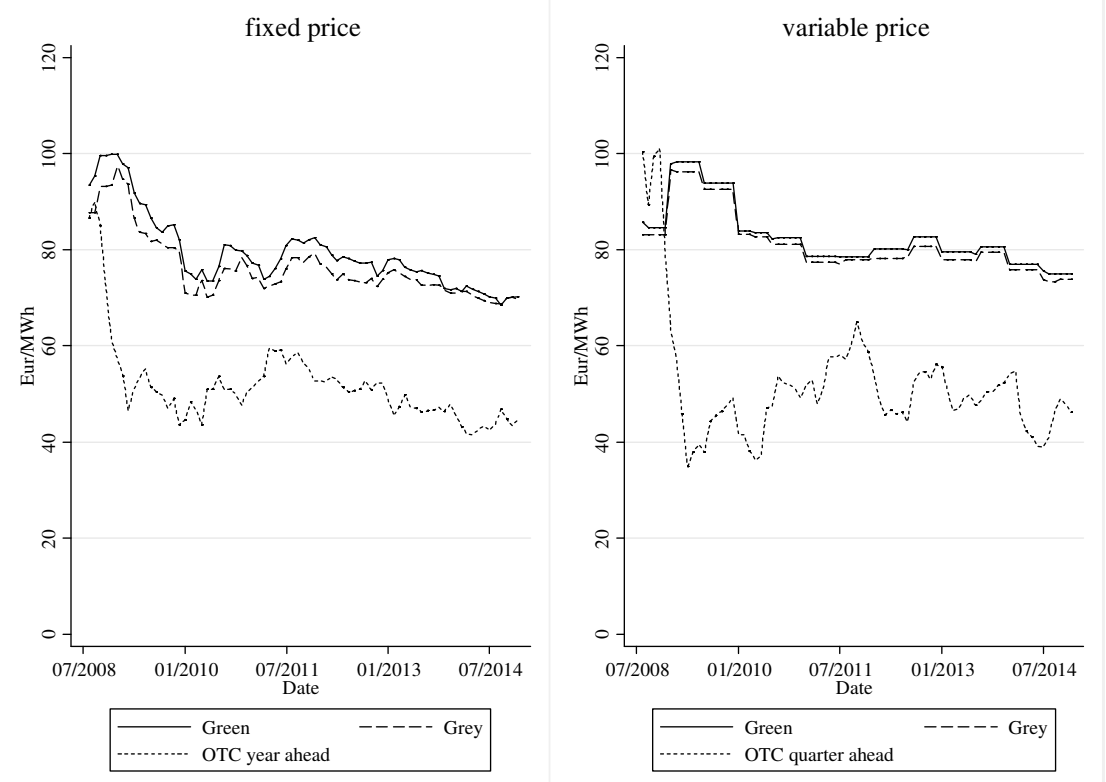

We find that the ratio between the retail price and the wholesale price is about 1.5 , which means that the mark-up for retailers is on average around 50\% (Table 3). The mark-up is higher for green than for grey products and has decreased over time. Given an average annual

${ }^{30}$ Besides the wholesale costs of the electricity, retailers also need to make some costs for acquiring green certificates. The price of these certificates appear to be only a few eurocents/MWh, except for specific types of green certificates, such as Dutch wind, which prices may be a few euro/MWh.

${ }^{31}$ The series for the variable retail prices and the quarterly forward prices, however, are not cointegrated. See Appendix A. 
consumption of 3.5 MWh, the yearly gross margin is about 90 EUR per household over the full sample. ${ }^{32}$ It is less for grey than for green products (Columns 2 and 3), and has decreased over time (Columns 4 and 5). Extrapolating the time trend of Table 3, we find that the savings for the average household are about 3 EUR per year on a total electricity bill of about 260 EUR. Of course, on individual level these benefits may be much larger.

Table 2 Retail price-regression for fixed- price contracts

\begin{tabular}{|c|c|c|c|c|c|}
\hline & $(1)$ & (2) & (3) & (4) & (5) \\
\hline Time Period & $09-14$ & $09-14$ & $09-14$ & $09-11$ & $12-14$ \\
\hline Green/Grey & Both & Green & Grey & Both & Both \\
\hline \multirow[t]{2}{*}{ Lag Retail Price } & $0.853 * * *$ & $0.799 * * *$ & $0.754 * * *$ & $0.784 * * *$ & $0.732 * * *$ \\
\hline & $(0.0139)$ & $(0.0215)$ & $(0.0292)$ & $(0.0260)$ & $(0.0301)$ \\
\hline \multirow[t]{2}{*}{ Wholesale Price } & $0.179 * * *$ & $0.216 * * *$ & $0.198 * * *$ & $0.230 * * *$ & $0.170 * * *$ \\
\hline & $(0.0240)$ & $(0.0303)$ & $(0.0387)$ & $(0.0440)$ & $(0.0303)$ \\
\hline \multirow[t]{2}{*}{ Constant } & 2.069 & $4.605 * * *$ & $8.307 * * *$ & 4.878 & $11.45 * * *$ \\
\hline & $(1.335)$ & $(1.748)$ & $(2.489)$ & $(3.029)$ & $(1.832)$ \\
\hline \# Observations & 725 & 444 & 281 & 338 & 387 \\
\hline R-squared & & 0.818 & 0.752 & 0.746 & 0.758 \\
\hline \# Products & 12 & 7 & 5 & 12 & 11 \\
\hline
\end{tabular}

Standard errors in parentheses; $* * * \mathrm{p}<0.01, * * \mathrm{p}<0.05, * \mathrm{p}<0.1$; with fixed effects

Table 3 Retail margins by contract type for different periods (Fixed price contracts)

\begin{tabular}{llllll}
\hline & $(1)$ & $(2)$ & $(3)$ & $(4)$ & $(5)$ \\
\hline Time Period & $09-14$ & $09-14$ & $09-14$ & $09-11$ & $12-14$ \\
Green / Grey & Both & Green & Grey & Both & Both \\
\hline Fixed mark-up $(€)$ & 14 & 21 & 34 & 23 & 42 \\
$\begin{array}{l}\text { Pass-through ratio } \\
\begin{array}{l}\text { Retail-wholesale } \\
\text { ratio }\end{array}\end{array}$ & 1.22 & 1.07 & 0.80 & 1.07 & 0.64 \\
$\begin{array}{l}\text { Gross margin } \\
\begin{array}{l}(€ / \text { household/year) } \\
\hline\end{array}\end{array}$ & 1.49 & 1.51 & 1.45 & 1.50 & 1.46 \\
\hline
\end{tabular}

32 The gross margin is used to cover the costs of administration, marketing, and price and credit risks. The remainder is the net margin, i.e. the retailer's profits. 


\subsection{Pass-through of wholesale costs}

The previous analysis shows a significant long-term relation between the 1-year fixed retail price and 1-year forward wholesale price. We now look at short term dynamics. Monthly changes in the retail price are, positively related with changes in the wholesale price, but this effect is not significant (Table 4). Deviations from the long-term price relationship affect the retail price. Both coefficients of the error term from the long-term relation have the expected, negative size, while the joint effect is statistically significant as well. However, we do not find evidence of asymmetric pass-through of wholesale costs, as we reject the hypothesis that the coefficients for the positive and negative residuals are different.

Table 4 Error-correction regression to test asymmetric pass-through

\begin{tabular}{|c|c|}
\hline Diff retail price & coefficient \\
\hline $\begin{array}{l}\text { Diff. wholesale price } \\
\text { residu }{ }_{(\mathrm{t}-1)} \\
\text { residu }-(\mathrm{t}-1) \\
\text { Constant }\end{array}$ & $\begin{array}{lr}0.0496 & (0.0445) \\
-0.142 * * * & (0.0503) \\
-0.279 * * * & (0.0936) \\
-0.381 & (0.267)\end{array}$ \\
\hline $\begin{array}{l}\text { Observations } \\
\text { R-squared }\end{array}$ & $\begin{array}{c}82 \\
0.284\end{array}$ \\
\hline \multicolumn{2}{|c|}{$\begin{array}{l}\text { Wald test on residuals of long-term relation (p- } \\
\text { value) }\end{array}$} \\
\hline $\begin{array}{l}\text { - joint significance } \\
\text { - different in size }\end{array}$ & $\begin{array}{l}0.00 \\
0.26\end{array}$ \\
\hline
\end{tabular}




\subsection{Consumers}

Consumers have become more satisfied with the energy retail market given the strong decline in the number of complaints at the Dutch Court of Arbitration (Figure 9). Immediately after the full opening of the retail market in 2004, the number of complaints rose sharply to more than 3000 in 2005 . These complaints were mostly related to problems with the switching process (NMa, 2008a). Triggered by these complaints and the societal debate on the functioning of the retail market, the regulator implemented a number of regulatory measures regarding information provision (guidelines, code of conduct as shown in Table 1).

Figure 9 Number of complaints of consumers regarding retail energy market (source: Dutch Court of arbitration)

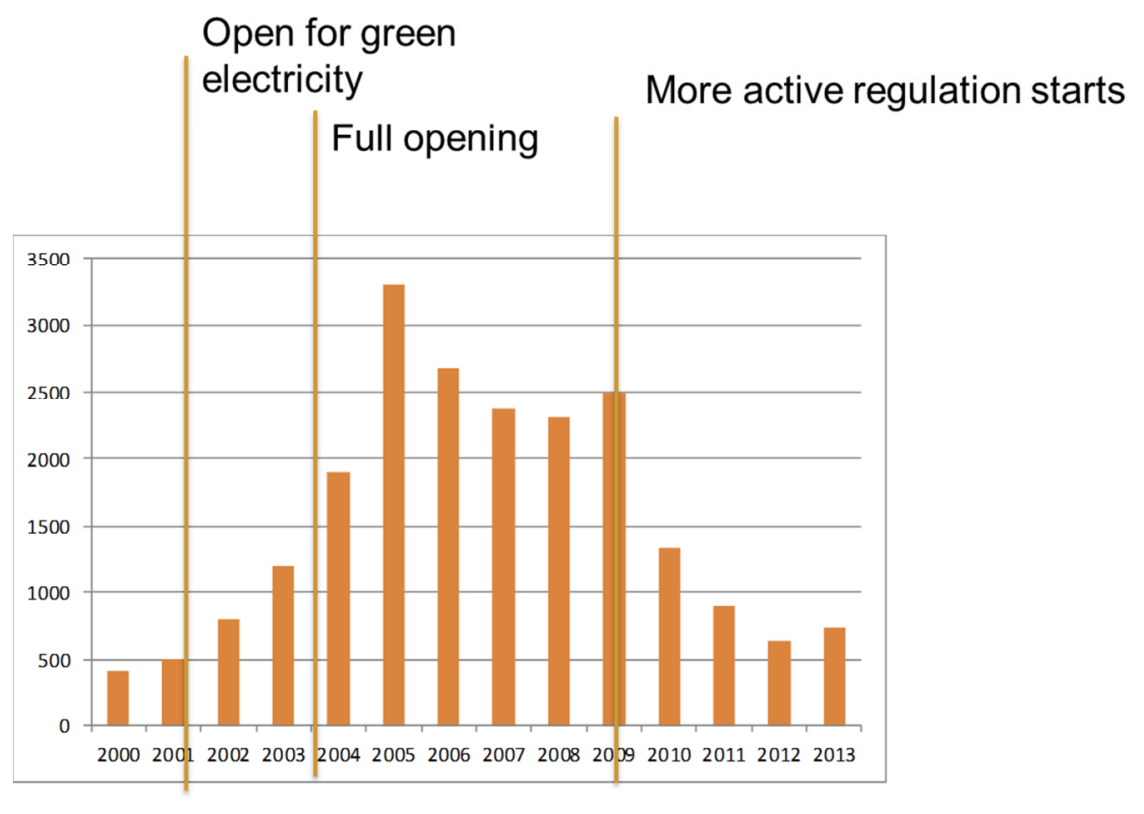

Annual switching rate increased gradually from about 5\% per year to almost 14\% in 2014 (see Figure 10). Compared to Dutch health-care insurance market (which was liberalized in 2006), energy consumers are fairly active. The degree of switching in the Dutch retail energy market is higher than in several other European countries, but lower than in the UK, Australia and New 
Zeeland (VAASA/ETT, 2012, ACER/CEER, 2015). Although the annual switching rate has increased, a significant amount of households (40\%) has never switched supplier (ACM, 2015).

Figure 10 Annual percentage of switching consumers in energy and health care (source: ACM, Vectis)

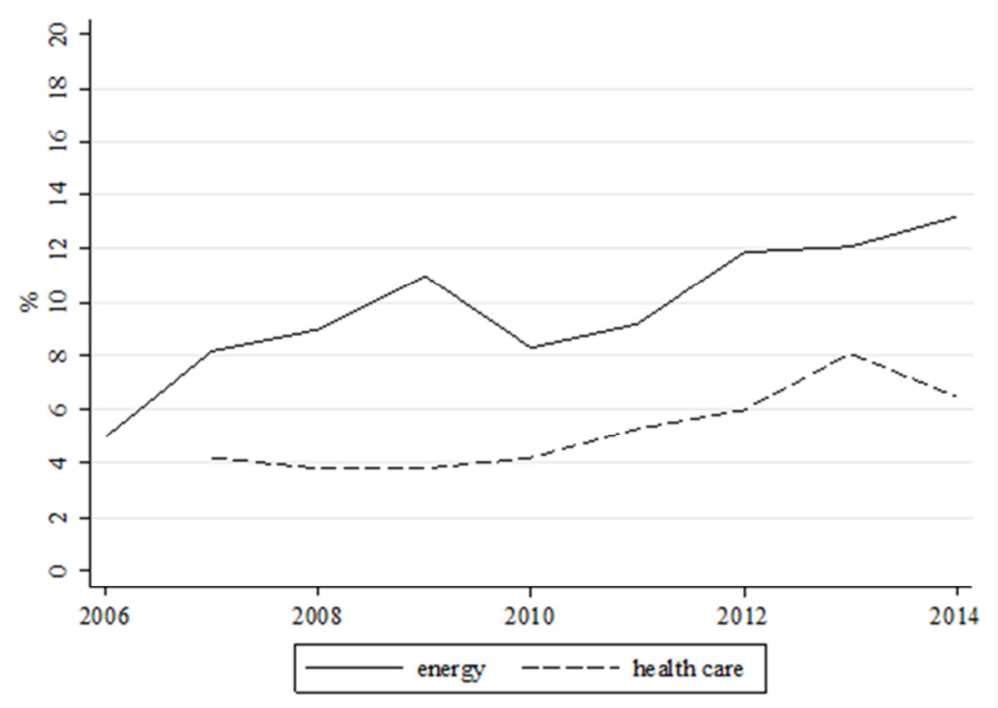

\section{CONCLUSIONS}

More than a decade since its liberalization, the Dutch electricity retail market have become matured. Switching rates continue to increase and are among the highest in Europe. The number of consumer complaints have almost returned to pre-liberalization levels. Products innovation is strong, in particular for green energy. As retailers spend much effort in explaining the essential product characteristics, comparison websites have improved information provision, and consumers are willing to pay a premium for green electricity, this is the likely to be the case for a substantial fraction of active households. Gross retail margins have decreased slightly, although this monetary benefit is estimated at only a few euros per household per year. Overall we, therefore, believe that consumers have benefited from market opening.

Price dispersion among firms has increased for green products as well as for variable-price products, suggesting that the market has become slightly less competitive. The price dispersion 
seems to be lower in Norwegian market. Delving into the dynamics of pricing strategies, we find, amongst others, that the frequency of price adjustments differs across firms, that there is no clear price leader, and that firms often undercut each other. This is consistent with Edgeworth type of competition. Over time, retail prices for fixed price products follow wholesale prices more closely, while there is no evidence for asymmetric pass-through of wholesale costs. The existence of the relative high price differences within and across contract types implies that the tariff surveillance which is meant to prevent unreasonable high prices does not result in low price differences, as was assumed by the IEA (2014). Hence, tariff surveillance in the energy retail market may leave sufficient room for price competition. Stimulating the use of standardized homogenous products could improve price competition, although it could also stifle innovation on product design. In addition, the Dutch experience shows that pushing standardized products is not an effective regulatory measure as the existing standardized product is hardly sold since retailers use other products to attract new customers.

The gross margin for the Netherlands is considerably higher than for Norway. This might indicate softer (price) competition in the Dutch retail market, but could also be related to differences in non-energy related retail costs. Gross retail margins are higher for green electricity, although the additional production costs are small. ${ }^{33}$ This indicates that the green retail market is less competitive, and retailers are able to capture the higher willingness-to-pay of consumers for green products (OECD, 2014).

From the strong decline in the number of complaints of Dutch consumers, we conclude that the confidence in the retail markets has increased. This result seems to be related to the implementation of a number of regulatory measures directed at the allocation of responsibilities

\footnotetext{
${ }^{33}$ Given the subsidies for green electricity, the price of Certificates of Origins is relatively small.
} 
between network operators and retailers as well as the information provision towards consumers.

These regulatory rules are increasingly based on general consumer legislation, which means that energy retail markets are now more treated as any other retail market. We conclude from this that a fairly intensive way of regulation is still needed to let mature retail energy market create benefits for consumers.

\section{References}

ACER/CEER (2015). Annual Report on the Results of Monitoring the Internal Electricity and Natural Gas Markets in 2014, Ljubljana/Brussels.

ACM (2014). Trendrapportage marktwerking en consumentenvertrouwen in de energiemarkt tweede halfjaar 2013. The Hague, April.

ACM (2015). Trendrapportage marktwerking en consumentenvertrouwen in de energiemarkt tweede halfjaar 2014. The Hague, April.

Anania, G. and R. Nisticò (2014). Price dispersion and seller heterogeneity in retail food markets. Food Policy 44: 190-201.

Armstrong (2014) Search and rip-off externalities. University of Oxford. ISSN 1471-0498

Atil, A., A. Lahiani and D.K. Nguyen (2014). Asymmetric and nonlinear pass-through of crude oil. prices to gasoline and natural gas prices, Energy Policy 65: 567-573.

Borenstein, S., \& Shepard, A. (2002). Sticky prices, inventories, and market power in wholesale gasoline markets. RAND Journal of Economics, 116-139.

Borenstein, S. (1991). Selling Costs and Switching Costs: Explaining Retail Gasoline Margins. The RAND Journal of Economics, 22(3), 354-369. http://doi.org/10.2307/2601052

Bessembinder, H. \& Lemmon, M. L. (2002). Equilibrium Pricing and Optimal Hedging in Electricity Forward Markets. The Journal of Finance. 57 (3), 1347-1382.

Bremmer, D.S. and R.G. Kesselring (2016). The relationship between U.S. Retail gasoline and crude oil prices during the great recession: "rockets and feathers" or "balloons and rocks" behavior? Energy Economics (available online)

Brown, J., and A. Goolsbee (2002) Does the Internet Make Markets More Competitive? Evidence from the Life Insurance Industry, Journal of Political Economy, 110(3), 481507.

Cabral, L. \& Fishman, A. (2012) Business as usual: A consumer search theory of sticky prices and asymmetric price adjustment. International Journal of Industrial Organization. 30 (4), 371-376.

CertiQ (2015). Annual reports CertiQ.

Damme, E.V. (2005). Liberalizing the Dutch electricity market: 1998-2004. The Energy Journal, 155-79 
Dixit, A. K., \& Stiglitz, J. E. (1977). Monopolistic Competition and Optimum Product Diversity. The American Economic Review, 67(3), 297-308.

DTe (2005). Marktmonitor, ontwikkeling van de groothandelsmarkt voor elektriciteit 2004 2005. The Hague, July.

DTe. (2004; 2005; 2006; 2007). Energieprijsvergelijkers. The Hague

Eckert, A. (2013). Empirical studies of gasoline retailing: A guide to the literature. Journal of Economic Surveys, 27, 140-166.

IEA (2008). Energy Policies of IEA countries: the Netherlands; 2018 Review. Paris.

IEA (2014). Energy Policies of IEA countries: the Netherlands; 2014 Review. Paris.

Lewis, M. S. (2011) Asymmetric Price Adjustment and Consumer Search: An Examination of the Retail Gasoline Market. Journal of Economics \& Management Strategy, 20 (2), 409-449.

Lewis, M. S., \& Marvel, H. P. (2011). When Do Consumers Search?*. The Journal of Industrial Economics, 59(3), 457-483. http://doi.org/10.1111/j.1467-6451.2011.00459.x

Fehr, Nils-Henrik M. von der, Petter Vegard Hansen, Electricity retailing in Norway, Department of Economics, University of Oslo, Memorandum 02/2009.

Hyland, M., E. Leahy and R.S.J. Tol (2013). The potential for segmentation of the retail market for electricity in Ireland. Energy Policy, 61: 349-359.

Littlechild, S. (2014). Promoting or restricting competition?: Regulation of the UK retail residential energy market since 2008. University of Cambridge, EPRG Working Paper 1415.

Marketresponse (2014) Stand van zaken op de energiemarkt - Onderzoek energiemarkt consumenten - Rapportage kerncijfers -Tweede halfjaar 2013 [online]. Available from: https://www.acm.nl/nl/publicaties/publicatie/12909/Stand-van-zaken-op-de-energiemarkt/ (Accessed 19 May 2014).

Meyer, J., \& von Cramon-Taubadel, S. (2004). Asymmetric Price Transmission: A Survey. Journal of Agricultural Economics, 55(3), 581-611. http://doi.org/10.1111/j.14779552.2004.tb00116.x

Mirza, F. M. \& Bergland, O. (2012) Pass-through of wholesale price to the end user retail price in the Norwegian electricity market. Energy Economics. 34 (6), 2003-2012.

Mulder, M., and V. Shestalova, (2006). Costs and Benefits of Vertical Separation of the Energy Distribution Industry: The Dutch Case. Competition and Regulation in Network Industries, 197-231.

Mulder, M. (2015) Competition in the Dutch Electricity Market: An Empirical Analysis over 2006-2011. The Energy Journal. 36 (2): 1-28.

Nakamura, E. \& Steinsson, J. (2011) Price setting in forward-looking customer markets. Journal of Monetary Economics. [Online] 58 (3), 220-233.

NMa (2008a). Rapportage naar aanleiding van het onderzoek naar onterechte switches. The Hague, April.

NMa (2008b). Monitor energiemarkten 2007; Analyse van ontwikkelingen in de Nederlandse groothandelsmarkten voor gas en elektriciteit. The Hague, September.

NMa (2010). Energieprijsvergelijkers 2010; Onderzoek naar de kwaliteit van vergelijkingssites voor elektriciteit en gas 
NMa (2011). Energieprijsvergelijkers 2011; Onderzoek naar de kwaliteit van websites die tarieven en voorwaarden van energieleveranciers vergelijken.

NMa (2012). "NMa geeft groen licht voor modelcontract energie", Press release, 6 April.

Nooij, M. de and B. Baarsma (2009). Divorce comes at a price: An ex ante welfare analysis of ownership unbundling of the distribution and commercial companies in the Dutch energy sector. Energy Policy, 37(12): 5449-5458.

Ofgem (2011a) What can behavioural economics say about GB energy consumers? London.

Ofgem (2011b) The Retail Market Review - Findings and initial proposals. London.

Ofgem (2011c) Do energy bills respond faster to rising costs than falling costs? London, 21 March.

OECD. (2014). Greening Household Behaviour: Overview from the 2011 Survey - Revised edition. OECD Publishing: OECD Studies on Environmental Policy and Household Behaviour.

Peltzman, S. (2000). Prices rise faster than they fall. Journal of Political Economy, 108, 466-502.

Tappata, M. (2009). Rockets and feathers: Understanding asymmetric pricing. The RAND Journal of Economics, 40(4), 673-687. http://doi.org/10.1111/j.1756-2171.2009.00084.x

VAASA/ETT (2012). World Energy Retail Market Rankings 2012.

Varian, H. R. (1980). A model of sales. The American Economic Review,70(4), 651-659.

Waddams Price, C. and M. Zhu (2016). Non-discrimination clauses: their effect on British retail energy prices. Energy Journal, 37(2): 111-132.

Wilson, C. and C. Waddams Price (2010). Do Consumers Switch to the Best Supplier?, Oxford Economic Papers 62.

Yang, H., \& Ye, L. (2008). Search with learning: understanding asymmetric price adjustments. The RAND Journal of Economics, 39(2), 547-564. http://doi.org/10.1111/j.07416261.2008.00027.x

\section{APPENDIX A}

Table A.1 Augmented Dickey-Fuller test on unit root*

\begin{tabular}{|c|c|c|c|c|c|}
\hline & & \multirow{2}{*}{$\begin{array}{l}\text { Retail prices } \\
\text { Variabl }\end{array}$} & \multicolumn{3}{|c|}{ Wholesale prices } \\
\hline & $\mathbf{e}$ & & Fixed & $\begin{array}{l}\text { Quarterly } \\
\text { forward }\end{array}$ & $\begin{array}{l}\text { Yearly } \\
\text { forward }\end{array}$ \\
\hline Level & & -2.5 & -1.9 & -2.2 & -2.2 \\
\hline $1^{\text {st }}$ difference & & -9.2 & -7.0 & -7.0 & -8.2 \\
\hline
\end{tabular}

* critical values: $1 \%$ : $-4.08 ; 5 \%:-3.47 ; 10 \%:-3.2$

Table A.2 Results of Johansen cointegration test between retail and wholesale prices

\begin{tabular}{lcc}
\hline Maximum rank & Trace statistic & $\mathbf{5 \%}$ critical value \\
\hline Variable retail price and quarterly-forward wholesale price & \\
0 & 42.0 & 15.4 \\
\hline
\end{tabular}




\begin{tabular}{lcl}
\hline 1 & 3.9 & 3.8 \\
Fixed retail price and yearly forward wholesale price & \\
0 & 19.4 & 15.4 \\
1 & $2.7^{*}$ & 3.8 \\
\hline
\end{tabular}




\section{List of research reports}

12001-HRM\&OB: Veltrop, D.B., C.L.M. Hermes, T.J.B.M. Postma and J. de Haan, A Tale of Two Factions: Exploring the Relationship between Factional Faultlines and Conflict Management in Pension Fund Boards

12002-EEF: Angelini, V. and J.O. Mierau, Social and Economic Aspects of Childhood Health: Evidence from Western-Europe

12003-Other: Valkenhoef, G.H.M. van, T. Tervonen, E.O. de Brock and H. Hillege, Clinical trials information in drug development and regulation: existing systems and standards

12004-EEF: Toolsema, L.A. and M.A. Allers, Welfare financing: Grant allocation and efficiency

12005-EEF: Boonman, T.M., J.P.A.M. Jacobs and G.H. Kuper, The Global Financial Crisis and currency crises in Latin America

12006-EEF: Kuper, G.H. and E. Sterken, Participation and Performance at the London 2012 Olympics

12007-Other: Zhao, J., G.H.M. van Valkenhoef, E.O. de Brock and H. Hillege, ADDIS: an automated way to do network meta-analysis

12008-GEM: Hoorn, A.A.J. van, Individualism and the cultural roots of management practices

12009-EEF: Dungey, M., J.P.A.M. Jacobs, J. Tian and S. van Norden, On trend-cycle decomposition and data revision

12010-EEF: Jong-A-Pin, R., J-E. Sturm and J. de Haan, Using real-time data to test for political budget cycles

12011-EEF: Samarina, A., Monetary targeting and financial system characteristics: An empirical analysis

12012-EEF: Alessie, R., V. Angelini and P. van Santen, Pension wealth and household savings in Europe: Evidence from SHARELIFE

13001-EEF: Kuper, G.H. and M. Mulder, Cross-border infrastructure constraints, regulatory measures and economic integration of the Dutch - German gas market

13002-EEF: Klein Goldewijk, G.M. and J.P.A.M. Jacobs, The relation between stature and long bone length in the Roman Empire

13003-EEF: Mulder, M. and L. Schoonbeek, Decomposing changes in competition in the Dutch electricity market through the Residual Supply Index

13004-EEF: Kuper, G.H. and M. Mulder, Cross-border constraints, institutional changes and integration of the Dutch - German gas market 
13005-EEF: Wiese, R., Do political or economic factors drive healthcare financing privatisations? Empirical evidence from OECD countries

13006-EEF: Elhorst, J.P., P. Heijnen, A. Samarina and J.P.A.M. Jacobs, State transfers at different moments in time: A spatial probit approach

13007-EEF: Mierau, J.O., The activity and lethality of militant groups: Ideology, capacity, and environment

13008-EEF: Dijkstra, P.T., M.A. Haan and M. Mulder, The effect of industry structure and yardstick design on strategic behavior with yardstick competition: an experimental study

13009-GEM: Hoorn, A.A.J. van, Values of financial services professionals and the global financial crisis as a crisis of ethics

13010-EEF: Boonman, T.M., Sovereign defaults, business cycles and economic growth in Latin America, 1870-2012

13011-EEF: He, X., J.P.A.M Jacobs, G.H. Kuper and J.E. Ligthart, On the impact of the global financial crisis on the euro area

13012-GEM: Hoorn, A.A.J. van, Generational shifts in managerial values and the coming of a global business culture

13013-EEF: Samarina, A. and J.E. Sturm, Factors leading to inflation targeting - The impact of adoption

13014-EEF: Allers, M.A. and E. Merkus, Soft budget constraint but no moral hazard? The Dutch local government bailout puzzle

13015-GEM: Hoorn, A.A.J. van, Trust and management: Explaining cross-national differences in work autonomy

13016-EEF: Boonman, T.M., J.P.A.M. Jacobs and G.H. Kuper, Sovereign debt crises in Latin America: A market pressure approach

13017-GEM: Oosterhaven, J., M.C. Bouwmeester and M. Nozaki, The impact of production and infrastructure shocks: A non-linear input-output programming approach, tested on an hypothetical economy

13018-EEF: Cavapozzi, D., W. Han and R. Miniaci, Alternative weighting structures for multidimensional poverty assessment

14001-OPERA: Germs, R. and N.D. van Foreest, Optimal control of production-inventory systems with constant and compound poisson demand

14002-EEF: Bao, T. and J. Duffy, Adaptive vs. eductive learning: Theory and evidence 14003-OPERA: Syntetos, A.A. and R.H. Teunter, On the calculation of safety stocks

14004-EEF: Bouwmeester, M.C., J. Oosterhaven and J.M. Rueda-Cantuche, Measuring the EU value added embodied in EU foreign exports by consolidating 27 national supply and use tables for 2000-2007 
14005-OPERA: Prak, D.R.J., R.H. Teunter and J. Riezebos, Periodic review and continuous ordering

14006-EEF: Reijnders, L.S.M., The college gender gap reversal: Insights from a life-cycle perspective

14007-EEF: Reijnders, L.S.M., Child care subsidies with endogenous education and fertility

14008-EEF: Otter, P.W., J.P.A.M. Jacobs and A.H.J. den Reijer, A criterion for the number of factors in a data-rich environment

14009-EEF: Mierau, J.O. and E. Suari Andreu, Fiscal rules and government size in the European Union

14010-EEF: Dijkstra, P.T., M.A. Haan and M. Mulder, Industry structure and collusion with uniform yardstick competition: theory and experiments

14011-EEF: Huizingh, E. and M. Mulder, Effectiveness of regulatory interventions on firm behavior: a randomized field experiment with e-commerce firms

14012-GEM: Bressand, A., Proving the old spell wrong: New African hydrocarbon producers and the 'resource curse'

14013-EEF: Dijkstra P.T., Price leadership and unequal market sharing: Collusion in experimental markets

14014-EEF: Angelini, V., M. Bertoni, and L. Corazzini, Unpacking the determinants of life satisfaction: A survey experiment

14015-EEF: Heijdra, B.J., J.O. Mierau, and T. Trimborn, Stimulating annuity markets 14016-GEM: Bezemer, D., M. Grydaki, and L. Zhang, Is financial development bad for growth?

14017-EEF: De Cao, E. and C. Lutz, Sensitive survey questions: measuring attitudes regarding female circumcision through a list experiment

14018-EEF: De Cao, E., The height production function from birth to maturity

14019-EEF: Allers, M.A. and J.B. Geertsema, The effects of local government amalgamation on public spending and service levels. Evidence from 15 years of municipal boundary reform

14020-EEF: Kuper, G.H. and J.H. Veurink, Central bank independence and political pressure in the Greenspan era

14021-GEM: Samarina, A. and D. Bezemer, Do Capital Flows Change Domestic Credit Allocation?

14022-EEF: Soetevent, A.R. and L. Zhou, Loss Modification Incentives for Insurers Under ExpectedUtility and Loss Aversion 
14023-EEF: Allers, M.A. and W. Vermeulen, Fiscal Equalization, Capitalization and the Flypaper Effect.

14024-GEM: Hoorn, A.A.J. van, Trust, Workplace Organization, and Comparative Economic Development.

14025-GEM: Bezemer, D., and L. Zhang, From Boom to Bust in de Credit Cycle: The Role of Mortgage Credit.

14026-GEM: Zhang, L., and D. Bezemer, How the Credit Cycle Affects Growth: The Role of Bank Balance Sheets.

14027-EEF: Bružikas, T., and A.R. Soetevent, Detailed Data and Changes in Market Structure: The Move to Unmanned Gasoline Service Stations.

14028-EEF: Bouwmeester, M.C., and B. Scholtens, Cross-border Spillovers from European Gas Infrastructure Investments.

14029-EEF: Lestano, and G.H. Kuper, Correlation Dynamics in East Asian Financial Markets.

14030-GEM: Bezemer, D.J., and M. Grydaki, Nonfinancial Sectors Debt and the U.S. Great Moderation.

14031-EEF: Hermes, N., and R. Lensink, Financial Liberalization and Capital Flight: Evidence from the African Continent.

14032-OPERA: Blok, C. de, A. Seepma, I. Roukema, D.P. van Donk, B. Keulen, and R. Otte, Digitalisering in Strafrechtketens: Ervaringen in Denemarken, Engeland, Oostenrijk en Estland vanuit een Supply Chain Perspectief.

14033-OPERA: Olde Keizer, M.C.A., and R.H. Teunter, Opportunistic condition-based maintenance and aperiodic inspections for a two-unit series system.

14034-EEF: Kuper, G.H., G. Sierksma, and F.C.R. Spieksma, Using Tennis Rankings to Predict Performance in Upcoming Tournaments

15001-EEF: Bao, T., X. Tian, X. Yu, Dictator Game with Indivisibility of Money

15002-GEM: Chen, Q., E. Dietzenbacher, and B. Los, The Effects of Ageing and Urbanization on China's Future Population and Labor Force

15003-EEF: Allers, M., B. van Ommeren, and B. Geertsema, Does intermunicipal cooperation create inefficiency? A comparison of interest rates paid by intermunicipal organizations, amalgamated municipalities and not recently amalgamated municipalities

15004-EEF: Dijkstra, P.T., M.A. Haan, and M. Mulder, Design of Yardstick Competition and Consumer Prices: Experimental Evidence

15005-EEF: Dijkstra, P.T., Price Leadership and Unequal Market Sharing: Collusion in Experimental Markets 
15006-EEF: Anufriev, M., T. Bao, A. Sutin, and J. Tuinstra, Fee Structure, Return Chasing and Mutual Fund Choice: An Experiment

15007-EEF: Lamers, M., Depositor Discipline and Bank Failures in Local Markets During the Financial Crisis

15008-EEF: Oosterhaven, J., On de Doubtful Usability of the Inoperability IO Model

15009-GEM: Zhang, L. and D. Bezemer, A Global House of Debt Effect? Mortgages and Post-Crisis Recessions in Fifty Economies

15010-I\&O: Hooghiemstra, R., N. Hermes, L. Oxelheim, and T. Randøy, The Impact of Board Internationalization on Earnings Management

15011-EEF: Haan, M.A., and W.H. Siekman, Winning Back the Unfaithful while Exploiting the Loyal: Retention Offers and Heterogeneous Switching Costs

15012-EEF: Haan, M.A., J.L. Moraga-González, and V. Petrikaite, Price and Match-Value Advertising with Directed Consumer Search

15013-EEF: Wiese, R., and S. Eriksen, Do Healthcare Financing Privatisations Curb Total Healthcare Expenditures? Evidence from OECD Countries

15014-EEF: Siekman, W.H., Directed Consumer Search

15015-GEM: Hoorn, A.A.J. van, Organizational Culture in the Financial Sector: Evidence from a Cross-Industry Analysis of Employee Personal Values and Career Success

15016-EEF: Te Bao, and C. Hommes, When Speculators Meet Constructors: Positive and Negative Feedback in Experimental Housing Markets

15017-EEF: Te Bao, and Xiaohua Yu, Memory and Discounting: Theory and Evidence

15018-EEF: Suari-Andreu, E., The Effect of House Price Changes on Household Saving

Behaviour: A Theoretical and Empirical Study of the Dutch Case

15019-EEF: Bijlsma, M., J. Boone, and G. Zwart, Community Rating in Health Insurance: Trade-off between Coverage and Selection

15020-EEF: Mulder, M., and B. Scholtens, A Plant-level Analysis of the Spill-over Effects of the German Energiewende

15021-GEM: Samarina, A., L. Zhang, and D. Bezemer, Mortgages and Credit Cycle Divergence in Eurozone Economies

16001-GEM: Hoorn, A. van, How Are Migrant Employees Manages? An Integrated Analysis

16002-EEF: Soetevent, A.R., Te Bao, A.L. Schippers, A Commercial Gift for Charity 16003-GEM: Bouwmeerster, M.C., and J. Oosterhaven, Economic Impacts of Natural Gas Flow Disruptions 
16004-MARK: Holtrop, N., J.E. Wieringa, M.J. Gijsenberg, and P. Stern, Competitive Reactions to Personal Selling: The Difference between Strategic and Tactical Actions

16005-EEF: Plantinga, A. and B. Scholtens, The Financial Impact of Divestment from Fossil Fuels

16006-GEM: Hoorn, A. van, Trust and Signals in Workplace Organization: Evidence from Job Autonomy Differentials between Immigrant Groups

16007-EEF: Willems, B. and G. Zwart, Regulatory Holidays and Optimal Network Expansion

16008-GEF: Hoorn, A. van, Reliability and Validity of the Happiness Approach to Measuring Preferences

16009-EEF: Hinloopen, J., and A.R. Soetevent, (Non-)Insurance Markets, Loss Size Manipulation and Competition: Experimental Evidence

16010-EEF: Bekker, P.A., A Generalized Dynamic Arbitrage Free Yield Model

16011-EEF: Mierau, J.A., and M. Mink, A Descriptive Model of Banking and Aggregate Demand

16012-EEF: Mulder, M. and B. Willems, Competition in Retail Electricity Markets: An Assessment of Ten Year Dutch Experience 
